\title{
Implementasi Pembelajaran Pendidikan Agama Islam Multikultural di MIN I Kota Malang
}

\author{
Fita Mustafida \\ Universitas Islam Malang, Indonesia \\ fita.mustafida@unisma.ac.id
}

\begin{abstract}
The spirit of national unity being tested now. Like violent conflicts in the name of religion, radicalism to terrorism. This is where the universal values of religion should be a driving force for humanity to build a more pluralist and inclusive religious understanding. Integrate of multiculturalism ideology in education is one of the efforts to provide education about pluralism and religious tolerance through schools (educational institutions). Therefore, multicultural Islamic education needs to be realized as a medium in providing solutions to conflicts caused by cultural differences in culture, religion, race, and other social conflicts. The aim of this study to describe, analyze, and interpret the implementation of multicultural Islamic education learning in Madrasah Ibtidaiyah Negeri (MIN) I Malang. The research approach uses was qualitative ethnographic types. The results showed that the learning process of Multicultural Islamic Religious Education was carried out by respecting and accommodating cultural diversity. So that it can be used as an ideal example of the application of Islamic Religious Education learning based on multicultural values, especially at the Islamic elementary school.
\end{abstract}

Keywords: learning; Islamic education; multicultural.

\begin{abstract}
Abstrak. Saat ini, semangat persatuan dan kesatuan bangsa sedang diuji. Sebut saja konflik-konflik kekerasan yang mengatasnamakan agama, radikalisme hingga terorisme. Disinilah nilai-nilai universal dari agama seharusnya menjadi pendorong bagi umat manusia untuk membangun pemahaman keagamaan yang lebih pluralis dan inklusif. Perkawinan ideologi multikulturalisme dalam pendidikan menjadi salah satu upaya untuk memberikan pendidikan tentang pluralisme dan toleransi beragama melalui sekolah (lembaga pendidikan). Oleh karena itulah, pendidikan agama Islam multikultural perlu direalisasikan sebagai media dalam memberikan solusi terhadap konflikkonflik yang diakibatkan perbedaan kultur budaya, agama, ras, dan konflik sosial yang lain. Penelitian ini bertujuan untuk mendeskripsikan, menganalisis, dan menginterpretasi terhadap implementasi pendidikan agama Islam multikultural di Madrasah Ibtidaiyah Negeri (MIN) I Kota Malang. Pendekatan penelitian menggunakan kualitatif dengan jenis etnografi. Proses pembelajaran Pendidikan Agama Islam multikultural dilakukan dengan menghargai dan mengakomodasi keragaman kultural. Sehingga hasil penelitian tersebut dapat dijadikan sebagai contoh ideal penerapan pembelajaran Pendidikan Agama Islam yang didasarkan nilai-niliai multikultural khususnya di tingkat Madarasah Ibtidaiyah (MI).
\end{abstract}

Kata Kunci: Pembelajaran; Pendidikan Agama Islam; Multikultural.

Copyright (C J-PAI: Jurnal Pendidikan Agama Islam. All Right Reserved.

This is an open access article under the CC BY-SA license

(https://creativecommons.org/licenses/by-sa/4.0/).

Correspondence Address: jpai@uin-malang.ac.id 
Fita Mustafida: Implementasi Pembelajaran Pendidikan Agama Islam...

\section{A. PENDAhUluan}

Filosofi perubahan kurikulum 2013 yang berakar dari budaya bangsa, menunjuk jelaskan tentang pentingnya mengimplementasikan pendidikan multikultural dalam ranah pendidikan sekolah. Madrasah Ibtidaiyah Negeri (MIN) I Kota Malang, yang selanjutnya disebut MIN I Kota Malang merupakan salah satu lembaga pendidikan yang merespon positif terhadap kebijakan pendidikan multikultural sebagaimana yang dijelaskan secara implisit dalam kurikulum 2013 tersebut.

Dari hasil penelitian tentang implementasi pendidikan multikultural di MIN I Kota Malang menunjukkan bahwa secara konsep dan implementasi MIN I Kota Malang telah menyelenggarakan pendidikan yang didasarkan pada nilai-nilai multikultural. Hal tersebut dapat dibuktikan dengan berbagai indikator praktek pendidikan multikultural yang diselenggarakan di sana. Secara konseptual pendidikan multikultural telah menyatu dengan visi, misi madrasah serta kurikulum yang diyakini kental dengan nilai multikultural. Visi MIN I Kota Malang adalah "Mewujudkan madrasah yang beriman, berakhlak mulia dan berprestasi." Melalui visi inilah MIN I Kota Malang dapat sejajar dengan sekolah-sekolah unggulan di Indonesia dari segi kualitas dan bidang prestasi akademik maupun non akademik. Adapun misi yang mengandung unsur multikultural antara lain; melahirkan lulusan yang berakhlak mulia, cinta tanah air, cerdas dan kreatif; menyelenggarakan pembelajaran yang inovatif dan berwawasan teknologi; menciptakan sumber daya manusia yang adaftif, kompetitif, dan kooperatif dengan mengembangkan multi kecerdasan; menumbuh kembangkan motivasi berprestasi dalam dimensi multi talenta.

Berpijak pada visi dan misi itulah segala aktivitas madrasah dikembangkan dengan hubungan yang harmoni baik siswa, guru karyawan dengan latar belakang yang berbeda. Nyatanya keragaman tersebut tidak menghalangi MIN I Kota Malang untuk menjadi madrasah yang unggul dan kompetitif. Pola interaksi yang terjalin di MIN I Kota Malang juga begitu hangat dan menyenangkan. Melalui tradisi senyum, sapa salam, salim, dan santun, menunjukkan sisi lain dari MIN I Kota Malang yang menggambarkan wajah Indonesia yang identik dengan ramah orangnya. Sikap saling menghormati, menghargai, tolong menolong dan kekeluargaan menjadi penyatu keberagaman di MIN I Kota Malang. Inilah sisi multikultural yang menjadi keunikan madrasah yang menjadi pusat pencontohan madrasah-madrasah swasta dan negeri di Malang Raya sebagaimana misinya menjadi pelopor bagi madrasah-madrasah yang lain.

Secara implementatif, pendidikan multikultural di MIN I Kota Malang tergambarkan dari adanya implementasi pembelajaran yang menghargai keragaman kultur. Proses pembelajaran ditekankan pada pembelajaran aktif, inovatif, kreatif, efektif, menyenangkan, produktif, Islami, dan berkesetaraan, yang ditunjang dengan berbagai fasilitas pembelajaran yang memadai, serta program pengembangan minat dan bakat untuk mewadahi semua kebutuhan dalam pengembangan potensi peserta didik yang beragam dalam bentuk kegiatan ekstra dan intra. Dalam pembelajaran agama (ubudiyah) tidak hanya didasarkan pada salah satu aliran paham keagamaan saja tetapi juga mengenalkan yang berbeda yang ada dan tumbuh di sekitar masyarakat.

Pembelajaran di kelas juga didasarkan pada nilai-nilai pendidikan multikultural. Antara lain; kondisi peserta didik yang heterogen; terdiri dari siswa yang beragam baik gender, umur, kemampuan, kecerdasan, ekonomi, modalitas, serta latar belakang keluarga. Pengajar atau guru di MIN I Kota Malang juga menunjukkan figur guru yang multikultural, yakni memiliki sikap adil terhadap peserta didik tanpa melihat perbedaan siswanya. Guru juga mampu menunjukkan kemampuannya dalam memahami keberagaman karakter siswa, sehingga dengan pemahaman tersebut dapat berkreasi dan berinovasi merekayasa kegiatan pembelajaran yang memperhatikan keragaman karakter peserta didik. Antara 
lain; menggunakan media pembelajaran yang bervariasi untuk memenuhi kebutuhan keragaman modalitas belajar peserta didik baik yang visual, auditorial, maupun kinestetik. Berupaya mengembangkan potensi ragam kecerdasan yang dimiliki anak melalui kegiatan dan pengalaman belajar di kelas. Selain itu guru juga menggunakan metode pembelajaran yang menjadikan semua siswa ikut terlibat dan dapat menerima perbedaan masing-masing individu, seperti diskusi, dan kerja kelompok.

Disamping pembelajaran di kelas, implementasi pendidikan agama Islam multikultural juga dilakukan melalui pembelajaran di luar kelas. Yakni tergambarkan melalui program pembiasaan agama dan akhlak mulia yang menjadi kultur MIN I Kota Malang. Diantaranya pembiasaan keagamaan, pembiasaan akhlak mulia, tradisi 5S (senyum, sapa, salim, sopan dan santun), budaya kerjasama, dan kebijakan nirbulliying bagi sivitas akademik MIN I Kota Malang. Pembelajaran agama di MIN I Kota Malang juga menggunakan pendekatan kontekstual melalui fieldtrip dan widyawisata yang ramah anak berbasis ICT dan berperspektif gender.

Berdasarkan implementasi berbagai kegiatan tersebut, ditemukan adanya relevansi terhadap praktek pendidikan multikultural yang berupaya untuk memenuhi dan mengembangkan keberagaman kelompok tanpa membedakan ras, etnis, dan budaya, serta berusaha untuk memberikan keterampilan kepada siswa agar aktif secara sosial dalam rangka menciptakan perubahan/rekonstruksi sosial telah dilakukan.

Atas dasar fenomena tersebut, maka pada tulisan ini akan membahas secara detail tentang bagaimanakah proses pembelajaran Pendidikan Agama Islam yang didasarkan pada Nilai-nilai Multikultural di MIN I Kota Malang dilaksanakan. Melalui implementasi tersebut dapat digambarkan secara detail baik konsep maupun implementasi proses pembelajaran pendidikan Agama yang didasarkan pada nilai-nilai multikulturalyang pada akhirnya dapat berkontribusi dalam menyumbangkan sebuah konsep implementasi pembelajaran Pendidikan Agama Islam multikultural untuk diterapkan di sekolah/madrasah.

\section{B. METODE PENELITIAN}

Penelitian ini menggunakan pendekatan kualitatif (qualitative approach). Pendekatan kualitatif dipilih, karena penelitian yang dilakukaan berlatar alamiah, bersifat deskriptif, dan cenderung menggunakan analisis induktif, yang mana proses dan makna (perspektif subyek) lebih ditonjolkan (Creswell, 2015). Dari ciri tersebut maka pendekatan kualitatif dipilih karena dalam pelaksanaannya, peneliti turut hadir, membaur dengan subjek yang diteliti, serta melakukan mengamatan terhadap prilaku, kegiatan dan tradisi yang menjadi budaya termasuk nilai-nilai dan keyakinan subjek sebagaimana fenomena yang berkembang di lapangan. Karena esensi dari penelitian ini adalah untuk memahami secara mendalam proses dan makna dari peristiwa yang berlangsung, sehingga jenis penelitiannya adalah etnografi. Dengan demikian, penelitian ini menempatkan tema dan isu tentang voice para subjek sebagai kebijakan penting untuk memahami bagaimana sebuah realitas sosial itu direpresentasikan (Cikusin, 2006).

Teknik analisis data yang digunakan menggunakan model analisis Spradley, analisis Spredley dalam penelitian etnografi yang peneliti lakukan merupakan upaya untuk menemukan pola-pola kultural dalam data berbagai data kultural yang telah diperoleh. Keesiig (1989) dalam (Hanifah, 2010) memaknainya sebagai pembuatan dokumentasi dan analisis budaya tertentu dengan mendeskripsikan suatu kebudayaan dengan pelukisan yang sistematis yang dihimpun dari lapangan dalam kurun waktu yang sama. Berikut disajikan gambaran tehnik analisis data penelitian dengan menggunkaan model Spredley: 
Fita Mustafida: Implementasi Pembelajaran Pendidikan Agama Islam...

Gambar 1.

Siklus Analisis Data Etnografi (Model Spredley)

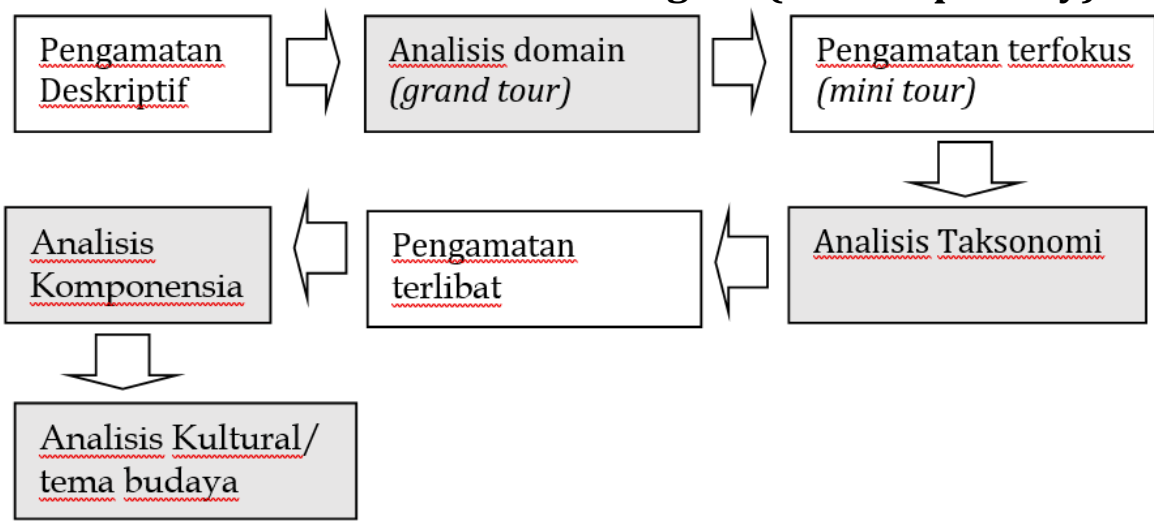

Berdasarkan gambar 1 di atas, maka langkah-langkah dalam merumuskan analisis data dimulai dari fokus penelitian kemudian untuk menjawab fokus digunakan 3 teknik pengumpulan data melalui observasi, wawancara, dokumentasi. Informasi data yang diperoh melalui kegiatan observasi, wawancara dan dokumentasi tersebut selanjutnya dianalis dan ditarik kesimpulan dengan analisis data sesuai hasil temuan di lapangan yang selanjutnya dalam analisis data tersebut dilakukan penentuan terhadap sistem kategori koding.

Untuk mengecek keabsahan data penelitian ini, dilakukan uji kebenaran setiap makna yang munculkan oleh data, secara rinci dapat dilihat pada pelaksanaan klarifikasi data. Meski demikian peneliti tidak hanya bersandar pada klarifikasi data, tetapi juga pada abstraksi data yang menunjang konfigurasi tidak begitu saja diambil dan dimasukkan, tetapi diklarifikasikan kembali dengan informan di lapangan ataupun diskusi dengan teman sejawat. Antara lain melalui audit internal dan eksternal. Audit internal yang dimaksud adalah dengan melakukan muhasabah atau refleksi terhadap pemahaman teori yang berhubungan dengan pendidikan multikultural dan proses pembelajaran Agama Islam sebagaimana terdapat pada landasan teori, dan metodologi dengan tahapan-tahapan berikut; 1) menggunakan teknik triangulasi teori, 2) member check, yaitu menkonfirmasi data yang diperoleh dilapangan baik itu data observasi, wawancara, maupun dokumentasi terkait dengan pembelajaran nilai-nilai pendidikan multikultural pada proses pembelajaran Pendidikan Agama Islam di lokasi penelitian.

\section{HASIL DAN PEMBAHASAN}

Dalam mengungkap Implementasi proses pembelajaran pendidikan agama Islam yang didasarkan pada nilai-nilai pendidikan multikultural di MIN I Kota Malang, digunakan salah satu konsep atau teori pendidikan multikultural yang banyak dianut para ahli, yaitu dimensi-dimensi proses pembelajaran multikultural (Banks, 2010). Teori ini digunakan untuk menganalisis prilaku dari aktivitas belajar mengajar dengan seluruh aspek atau komponen pembelajaran mata pelajaran Pendidikan Agama Islam yang meliputi empat mata pelajaran rumpun pendidikan agama Islam, yakni Qur'an Hadis, Akidah Akhlak, Fiqih, dan Sejarah Kebudayaan Islam (SKI) di MIN I Kota Malang.

Pembelajaran pendidikan agama Islam menjadi fokus kajian penelitian ini dikarenakan pendidikan agama Islam memiliki nilai-nilai universal yang selaras dengan nilai-nilai multikultural yang penting diinternalisasikan kepada peserta didik (Suryana, 2015). Selain itu, pendidikan agama Islam merupakan mata pelajaran wajib bagi siswa mulai dari kelas satu sampai dengan kelas enam, kecuali Sejarah Kebudayaan Islam (SKI) yang wajib dipelajari mulai dari kelas tiga. Oleh karena itu, mata pelajaran Pendidikan Agama Islam memiliki posisi strategis dalam penanamkan nilai-nilai multikultural (Mahfud, 2019). 
Berikut disajikan analisis proses pembelajaran Pendidikan Agama Islam Multikultural yang didasarkan pada nilai-nilai multikultural di MIN I Kota Malang yang digambarkan melalui langkah-langkahnya sebagai berikut:

\section{Perencanaan Pembelajaran Pendidikan Agama Islam yang Didasarkan Nilai Multikultural}

Perencanaan merupakan tugas pertama bagi guru sebelum melaksanakan kegiatan pembelajaran di kelas. Dengan kata lain, seorang guru dalam mengembangkan aktivitas pembelajaran apapun yang harus mereka lakukan adalah merencanakan, kemudian menerapkan rencana-rencana tersebut dan akhirnya menilai keberhasilan aktivitasnya (Jacobsen, David, Paul Enggen, 2009).

Perencanaan yang baik harus menguasai keadaan yang ada pada saat itu. Dari kondisi yang ada itulah berbagai proyeksi dapat dilakukan dan kemudian dituangkan dalam bentuk rangkaian kegiatan dalam perencanaan. Oleh sebab itu, rekayasa-rekayasa kegiatan belajar mengajar (strategi) yang mampu menjadikan pembelajaran menyenangkan serta memudahkan dalam pencapaian kompetensi yang diharapkan amat diperlukan. Disinilah perlunya guru memiliki pemahaman terhadap konsep-konsep strategi, metode, dan tehnik dalam kegiatan belajar mengajar yang sesuai dengan kebutuhan peserta didik dan kebutuhan dalam pencapaian tujuan pembelajaran tersebut.

Dari hasil analisis temuan kegiatan perencanaan pembelajaran mata pelajaran Pendidikan Agama Islam di MIN Kota Malang, ditemukan bahwa rencana pelaksanaan pembelajaran (RPP) mata pelajaran Pendidikan Agama Islam telah didasarkan pada nilainilai multikultural. Hal tersebut dibuktikan dengan adanya muatan nilai-nilai pendidikan agama Islam multikultural pada komponen RPP yang disusun oleh guru.

Nilai-nilai multikultural sebagaimana dimaksud ditemukan melalui proses analisis terhadap komponen RPP dengan teori-teori tentang nilai-nilai multikultural seperti nilai demokrasi, kesetaraan, dan keadilan; nilai kemanusiaan (humanis), kebersamaan, dan kedamaian; sikap sosial, pengakuan, penerimaan, dan penghargaan kepada orang lain sebagaimana dikemukakan (Aly, 2015).

\section{a. Muatan Nilai Multikultural dalam Kompetensi Inti Sikap Spiritual dan Sikap Sosial (KI-1 dan KI-2)}

Meskipun kompetensi inti sikap spiritual dan sikap sosial tidak diajarkan secara langsung dalam bentuk materi pelajaran kepada siswa, namun kompetensi ini tetap menjadi acuan dalam pembentukan kompetensi sikap siswa melalui penanaman nilai dan sikap. Diantara muatan nilai-nilai dalam kompetensi sikap spiritual dan sosial siswa Madrasah Ibtidaiyah di MIN I Kota Malang adalah sebagai berikut:

Tabel 1.

Kompetensi inti dan muatan nilai pendidikan Islam multikultural

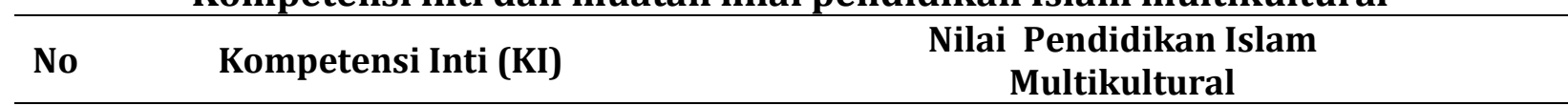

$\underline{\text { Kelas } 1 \text { dan } 2}$

1. Menerima dan menjalankan ajaran agama yang dianutnya.
Nilai keimanan, sebagai dasar bagi pemeluk agama, dan nilai kesadaran beragama

1

2. Memiliki perilaku jujur, Belajar hidup dalam perbedaan, saling percaya, saling disiplin, tanggung Jawab, pengertian, saling menghargai, perduli terhadap orang santun, peduli, dan percaya diri dalam berinteraksi dengan lain, dan nilai humanis (kemanusiaan) sebagai wujud keluarga, teman, dan Guru.

$2 \quad$ Kelas 3 dan 4

1. Menerima dan menjalankan 
Fita Mustafida: Implementasi Pembelajaran Pendidikan Agama Islam...

ajaran agama yang dianutnya. Nilai keimanan, sebagai dasar bagi pemeluk agama, dan nilai kesadaran beragama

2. Perilaku jujur, disiplin, tanggung Jawab, santun, Belajar hidup dalam perbedaan, saling percaya, saling peduli, dan percaya diri dalam berinteraksi dengan keluarga, teman, guru dan tetangganya. pengertian, saling menghargai, perduli terhadap orang lain, dan nilai humanis (kemanusiaan) sebagai wujud dari interaksi sosial dengan keluarga, teman, guru dan tetangga.

\section{Kelas 5 dan 6}

1. Menerima, menjalankan, dan menghargai ajaran agama yang dianutnya.

Nilai keimanan, sebagai dasar bagi pemeluk agama, dan nilai kesadaran beragama

2. Menunjukkan perilaku jujur, disiplin, tanggung Jawab, santun, peduli, dan percaya diri dalam berinteraksi dengan keluarga, teman, guru, dan tetangganya serta cinta tanah air.

Nilai demokrasi, kesetaraan, dan keadilan, belajar hidup dalam perbedaan, saling percaya, saling pengertian, saling menghargai, perduli sesama, kebersamaan, dan cinta tanah air

\section{b. Nilai dalam Kompetensi Dasar dan Materi Pembelajaran}

\section{Tabel 2.}

Kompetensi inti dan muatan nilai pendidikan Islam multikultural

No $\begin{aligned} & \text { Mata } \\ & \text { pelajaran }\end{aligned} \quad$ Kelas $\begin{aligned} & \text { Kompetensi } \\ & \text { Dasar }\end{aligned} \quad$ Materi $\quad$ Muatan Nilai Multikultural

1. Qur'an Hadis III 2.1 Mengenal Surat At-Tin Pengamalan isi kandungan surat at QS. At-tiin (101) tiin dalam lingkup sosial dengan secara benar keluarga, teman dan guru. Yaitu dan fasih dengan menerima dan menghargai perbedaan bentuk ciptaan yang merupakan pemberian dari Allah, ada laki-laki ada perempuan, ada yang berkulit putih, cokelat atau hitam, ada yang berambut lurus, keriting dan sebagainya.

\begin{tabular}{llll}
\hline 2. Fiqih & III & $\begin{array}{l}3.2 \text { Memahami } \\
\text { ketentuan } \\
\text { sholat tarawih }\end{array}$ & $\begin{array}{l}\text { Ketentuan } \\
\text { Sholat } \\
\text { Tarawih }\end{array}$
\end{tabular}

Pemahaman siswa tentang pengertian, ketentuan, dan hukum shalat tarawih sesuai dengan kaidah fiqih yang diajarkan dengan prinsip multikultural yakni terbuka dalam berpikir dan menghargai atas keragaman madzhab fiqih dengan mengenalkan perbedaan ketentuan jumlah rakaat shalat tarawih.

\begin{tabular}{llll}
\hline 3. Akidah & VI & 2.1 Mencontoh & Asmaul \\
& sifat Allah SWT. Husna \\
& sebagai al- \\
& Gafur, al-Afuw, \\
& as-Shabur dan \\
& al-Halim.
\end{tabular}

Ditunjukkan dengan membiasakan
berakhlak/berprilaku tentang
adanya keyakinan terhadap Allah
SWT sebagai al-ghafur (maha
pemaaf), al-a'fuw (maha
pengampun), as- shabur (maha
sabar), dan al-halim (maha
bijaksana). Dengan pengamalan




\begin{tabular}{|c|c|c|c|c|}
\hline & & & & $\begin{array}{l}\text { nilai hidup bersamana dalam } \\
\text { perbedaan dengan mudah } \\
\text { memaafkan, sabar dan bijak dalam } \\
\text { menghadapi sebuah permasalahan, } \\
\text { serta memiliki pemahaman akan } \\
\text { pentingnya hidup bersama dalam } \\
\text { perbedaa dan berpikir inklusif }\end{array}$ \\
\hline $4 \quad$ SKI & IV & $\begin{array}{l}1.1 \\
\text { Mengamalkan } \\
\text { sholat lima } \\
\text { waktu secara } \\
\text { tertib sebagai } \\
\text { bentuk } \\
\text { pengamalan } \\
\text { peristiwa isra' } \\
\text { mi'raj Nabi } \\
\text { Muhammad } \\
\text { SAW. }\end{array}$ & $\begin{array}{ll}\text { Isra' dan } \\
\text { Mi'raj }\end{array}$ & $\begin{array}{l}\text { Mengamalkan shalat lima waktu } \\
\text { secara tertib sebagai bentuk } \\
\text { pengamalan peristiwa isra' mi'raj } \\
\text { Nabi Muhammad SAW, yang } \\
\text { merupakan implementasi dari } \\
\text { kesadaran beragaman melalui } \\
\text { keyakinan bahwa shalat } 5 \text { waktu } \\
\text { adalah perintah Allah. }\end{array}$ \\
\hline
\end{tabular}

\section{c. Nilai Pendidikan Islam Multikultural dalam Metode Pembelajaran}

Metode pembelajaran yang multikultural adalah metode pembelajaran yang mampu menghargai dan mengakomodasi keragaman kultur peserta didik. Adapun nilai pendidikan Islam mutikultural dalam metode pembelajaran yang digunakan guru MIN I Kota Malang antara lain adalah nilai kebersamaan, toleransi, kesetaraan dan keadilan.

Nilai kebersamaan diimplementasikan melalui berbagai metode pembelajaran aktif dan kerja kelompok (Race, 2015). Melalui kerja kelompok maka interaksi sosial siswa dapat berkembang dengan baik. Sebagaimana (Kymlicka, 2002) menyatakan bahwa kesatuan sosial tergantung tergantung dari nilai-nilai yang dimiliki bersama. Dengan memusatkan pada nilai-nilai bersama itu akan memberikan landasan bagi kesatuan sosial. Diantara metode pembelajaran yang memuat nilai kebersamaan di MIN I Kota Malang adalah metode diskusi, problem based learning dan pembelajaran berbasis proyek. Sementara nilai toleransi kesetaraan dan keadilan juga ditunjukkan melalui implementasi metode pembelajaran yang menghargarai keragaman peserta didik, seperti penggunakan media pembelajaran yang bervaritaif sehingga dapat mengakomodasi perbedaan tipe/modalitas belajar siswa (Ghofur dan Mustafida, 2019). Nilai kesetaraan dan keadilan diimplementasikan melalui metode tanya jawab yang memberikan kesempatan sama kepada peserta didik tanpa melihat latar belakangnya. Selain itu metode pembelajaaran yang digunakan guru juga diarahkan untuk memberikan hak yang sama bagi siswa untuk terlibat langsung dalam kegiatan belajar, seperti inquiry dan cooperatif learning.

Berdasarkan muatan nilai-nilai multikultural dalam komponen RPP yang disusun oleh guru agama di MIN I Kota Malang sudah mengarah pada rencana kegiatan pembelajaran yang didasarkan pada nilai-nilai multikultural.

\section{Pelaksanaan Pembelajaran Pendidikan Agama Islam yang didasarkan nilai-nilai multikultural}

Pembelajaran merupakan proses kultural yang terjadi dalam konteks sosial. Agar pembelajaran dapat diakses yang sama oleh siswa, maka secara otomatis harus dipahami kebudayaannya (Baidhawy, 2005). Terkait dengan pelaksanaan pembelajaran Pendidikan Agama Islam di MIN I Kota Malang, menunjukkan adanya indikasi proses pembelajaran yang telah didasarkan pada nilai-nilai pendidikan Islam multikultural. Hal ini dapat terlihat dari langkah-langkah kegiatan pembelajaran yang memperhatikan dan menghargai dimensi-dimensi multikultur. Yakni mengintegrasikan nilai-nilai multikultural dalam 
Fita Mustafida: Implementasi Pembelajaran Pendidikan Agama Islam...

materi pembelajaran. Sebagai contoh materi pengamalan isi kandungan surat at-tiin dalam lingkup sosial dengan keluarga, teman dan guru. Pada materi ini siswa diberi pemahaman tentang menerima dan menghargai perbedaan bentuk ciptaan yang merupakan pemberian dari Allah, ada laki-laki ada perempuan, ada yang berkulit putih, coklat atau hitam, ada yang berambut lurus, dan keriting. Pada materi Fiqih juga diajarkan tentang tentang pengertian, ketentuan, dan hukum shalat tarawih sesuai dengan kaidah Fiqih yang diajarkan dengan prinsip multikultural yakni terbuka dalam berpikir dan menghargai atas keragaman madzhab fiqih dengan mengenalkan perbedaan ketentuan jumlah rakaat shalat tarawih.

Inilah yang menjadikan salah satu materi mata pelajaran agama di MIN I Kota Malang disampaikan dengan menjunjung nilai-nilai toleransi untuk menghargai perbedaan ajaran melaksanakan sholat tarawih dengan jumlah bilangan rakaat yang berbeda, kebebasan, dalam menentukan pilihan, untuk melaksanakan sholat tarawih dalam jumlah 8, 20 rakaat, mandiri melalui ajaran sholat tarawih bisa dilakukan berjamaah maupun sendiri. Disiplin tepat waktu, dan kerjasama melalui sholat berjamaah yang afdhol. Sementara materi Akidah Akhlak diajarkan dengan membiasakan berakhlak/berprilaku tentang adanya keyakinan terhadap Allah SWT sebagai al-ghafur (maha pemaaf), al-a'fuw (maha pengampun), as- shabur (maha sabar), dan al-halim (maha bijaksana). Dengan pengamalan nilai hidup bersamana dalam perbedaan dengan mudah memaafkan, sabar dan bijak dalam menghadapi sebuah permasalahan, serta memiliki pemahaman akan pentingnya hidup bersama dalam perbedaa dan berpikir inklusif. Integrasi materi multikultural dalam pembelajaran merupakan dimensi proses pendidikan multikultural yang pertama dalam (Banks, 2010)

Selain intergrasi materi dalam pembelajaran Pendidikan Agama Islam, pelaksanaan pembelajaran juga dilakukan dengan membangun konsep pengetahuan yang multikultural melalui berbagai metode pembelajaran yang digunakan, seperti metode diskusi, problem based learning dan pembelajaran berbasis proyek yang berprinsip pada nilai-nilai kebersamaan, toleransi, kesetaraan dan keadilan. Hal ini berkeseuaian dengan (Zamroni, 2011) bahwa implementasi pembelajaran demokrasi multikultur harus berprinsip pada nilai-nilai kesetaraan dan keadilan disamping toleransi.

Metode diskusi diimplementasikan dengan membagi kelompok yang terdiri dari siswa laki-laki dan perempuan dengan kemampuan yang beragam pula. Dengan demikian anak dapat menghargai perbedaan temannya melalui interaksi dan komunikasi di dalam tim (Rosyidi, 2009). Untuk mengakomodir keragaman modalitas belajar siswa guru juga menggunakan metode pembelajaran yang dapat melibatkan aktifitas gerak siswa. Seperti menghafalkan surat At-tin dengan menggunakan gerakan tangan, ke atas melingkar, membuka dan menutup. Melalui pembelajaran yang menghargai keragaman tersebut, (Baidhawy, 2005) mengandaikan sebuah pendidikan agama yang berwawasan multikultural. (Ghofur dan Mustafida, 2019) bersepakat jika upaya pembelajaran yang menghargai keragaman kultur mampu menciptakan atmosfir pembelajaran yang lebih demokratis, tidak ada tekanan dan saling terbuka satu sama lain.

Kajian tersebut diperkuat melalui langkah-langkah pembelajaran yang dilakukan oleh guru Pendidikan Agama Islam di MIN I Kota Malang mulai dari kegiatan pendahuluan, kegiatan inti dan kegiatan penutup yang menghargai dan mengakomodasi keragaman kultural sebagaimana penjelasan berikut:

\section{a. Kegiatan pendahuluan}

Dalam kegiatan ini, guru menyapa siswa dengan mengucapkan salam, dan menanyakan kabar untuk menumbuhkan rasa perduli dan menjalin kedekatan emosional dengan intonasi yang sesuai serta wajah yang penuh keceriaan, berdoa untuk membudayakan penguatan keimanan kepada tuhan yang maha Esa, dilanjutkan dengan 
kegiatan apersepsi yang bervariasi untuk menyiapkan dan memotivasi siswa dalam mengikuti pembelajaran dengan memperhatikan karakteristik dan tahap perkembangan anak, yakni dengan mengunakan variasi gaya mengajar, menggunakan media pembelajaran yang mengakomodir semua tipe gaya belajar siswa, serta pola interaksi pembelajaran yang ramah perbedaan, menjalin kebersamaan, dan demokratis.

Pemberdayaan suasana awal kegiatan pembelajaran yang demikian merupakan upaya pengorganisasian yang dilakukan guru dalam mewujudkan suasana belajar kondusif sehingga mendukung bagi pertumbuhan akademis dan emosi semua siswa (Slavin, 2009). Lebih lanjut, Smith mengemukakan bahwa proses pembelajaran nilai multikultural di sekolah atau lingkungan pendidikan harus dikondisikan sebagai tempat interaksi sosial dari seluruh elemen yang beragam secara educative demokratis yang terkonstruksi dengan setting yang dinamis, agar proses komunikasi dan interaksi edukatif dari seluruh elemen yang beragam dapat berlangsung efektif (Smith, 2002). Oleh karena itu, pelaksanaan kegiatan pendahuluan yang dikembangkan guru MIN I Kota Malang kental dengan nilainilai multikultural.

\section{b. Kegiatan Inti}

Pada kegaiatan ini mengacu pada pendekatan scientific yang menerapkan 5M, yakni mengamati, menanya, mengeksplorasi, mengasosiasi, dan mengkomunikasi (Mulyasa, 2013) yang dilakukan melalui berbagai strategi dan metode pembelajaran yang variatif dan berpusat pada siswa yang diarahkan untuk mengimplementasikan pembelajaran kooperatif. Seperti diskusi kelompok, projek kelompok maupun individu, diskusi kelas, team quis. Pemilihan metode ini sesuai dengan yang dikemukakan oleh (Banks, 2010) bahwa implementasi strategi dan metode pembelajaran yang direkomensadikan untuk pembelajaran multikultural adalah cooperatif learning, role playing, serta variasi pembelajaran yang dapat menciptakan pengalaman untuk mengembangkan apresiasi terhadap orang lain.

Dalam penerapannya, MIN I Kota Malang juga berusaha untuk mengimplementasikan isi kurikulum nasional (K-13) dalam keseharian di sekolah melalui proses pembelajaran yang menghargai keragaman dan upaya melestarikan budaya nusantara. Sebagai contoh pada tema puncak di kelas lima, semua kelas menampilkan satu budaya daerah, masing-masing kelas mengambil salah satu budaya yang ada di propinsi di Indonesia, kemudian menampilkan keanekaragaman budaya tersebut, mulai dari taritarian, pakaian adat, makanan khas, musik tradisional dan sebagainya. Hal ini dilakukan untuk memberikan pemahaman kepada peserta didik tentang keanekaragaman budaya di Indonesia yang perlu di kembangkan dan dilestarikan sehingga menjadikan peserta didik bangga menjadi anak Indonesia dan berjiwa toleran.

Melalui metode tersebut sehingga pembelajaran tetap mengindahkan nilai-nilai cinta tanah air, kerjasama, saling menghargai pendapat, kebebasan (fressdon), kesederajatan, keadilan, dan percaya diri yang terlukiskan dari bagaimana siswa mampu menghargai pendapat teman dari pertanyaan ataupun tanggapan atas pertanyaan yang dibuat guru atau siswa, kegiatan mengkomunikasikan hasil tugas atau hasil kegiatan asosiasi yang dilakukan siswa atas panduan guru, seperti hasil peta konsep, dan rangkuman.

Selain itu, guru juga perlu memadukan pendekatan pembelajaran yang multkutural dengan keteladanan guru. Hal ini ditunjukkan dengan sikap guru yang multikulturalis yakni memberikan kesempatan yang sama kepada siswa untuk menjawab pertanyaan, menanggapi dan memberikan masukan dalam berdiskusi. Bahkan banyak keunikan yang dilakukan guru untuk memberika porsi kesempatan yang sama kepada anak melalui permainan atau tabak-tebakan siapa yang mampu menjawab dengan benar tebakan guru maka berkesempatan untuk maju ke depan kelas. Ada pula yang mengajak siswa bernyanyi 
Fita Mustafida: Implementasi Pembelajaran Pendidikan Agama Islam...

dan ketika nyanyian berhenti/selesai pada salah satu siswa, maka siswa tersebutlah yang berkesempatan untuk menjawab pertanyaan dan sebagainya. Rekayasa-rekayasa seperti ini nyatanya mampu menunjukkan sikap guru yang humanis, adil terhadap siswa, menjunjung tinggi prinsip-prinsip kesetaraan (egaliter) dan demokratis sebagaimana yang dikemukakan oleh (Misrawi, 2013).

Dengan kata lain pelaksanaan kegiatan inti pembelajaran di MIN I Kota Malang menggunakan metode pembelajaran yang didasarkan nilai-nilai multikultural yaitu dengan menggunakan metode pembelajaran yang berpusat pada siswa, antara lain melalui kegiatan diskusi, kerja kelompok, dan unjuk kerja dan atau presentasi yang mengedepankan prinsip-prinsip kerjasama, saling menghargai, kesetaraan, dan keadilan dengan mengembangkan multi kecerdasan. Hal ini relevan dengan( Nata, 2005) yang mensyaratan Pendidikan Agama Islam mengubah cara belajar dari model warisan kepada model belajar pemecahan masalah, dari model hafalan ke dialog, dari pasif ke aktif, dari memiliki (to have) ke menjadi (to be), dari mekanis ke kreatif, dari menguasai materi sebanyak-banyaknya ke menguasai metodologi yang kuat, dari memandang dan menerima ilmu sebagai hasil final yang mapan menjadi memandang dan menerima ilmu sebagai yang berbeda dalam dimensi proses.

\section{c. Kegiatan penutup}

Pada kegiatan Penutup guru selalu mengajak siswa untuk merefleksi pembelajaran melalui hasil temuan siswa dari konsep materi yang baru saja dipelajari untuk dievalusi bersama-sama dan dibuat simpulan oleh siswa yang dipandu oleh guru. Diakhir pertemuan guru juga selalu berpesan untuk belajar di rumah, serta memberikan nasihat-nasihat untuk pengembangan nilai dan sikap multikultural.

Berdasarkan penjelasan di atas, maka dapat ditarik kesimpulan bahwa pelaksanaan pembelajaran Pendidikan Agama Islam di MIN I Kota Malang telah sesuai dengan prinsip pendidikan multikultural. Hal tersebut tercermin dari figur guru serta praktek pembelajaran yang menghargai keragaman kultur peserta didik, yang dibuktikan melalui gaya mengajar guru yang bervariasi, orientasi pembelajaran aktif, adanya kerjasama, saling menghargai, kesetaraan, dan keadilan dengan mengembangkan segala potensi, modalitas belajar maupun kecerdasan peserta didik.

\section{Penilaian Pembelajaran Pendidikan Agama Islam yang Multikultural}

Dari hasil temuan penelitian tentang implementasi proses pembelajaran Pendidikan Agama Islam di MIN I Kota Malang diperoleh bahwa penilaian pembelajaran Pendidikan Agama Islam di MIN I Kota Malang dilakukan secara menyeluruh dan kompreshensif. Hal ini dibuktikan dengan adanya ragam penilaian yang digunakan untuk menilai pengetahuan, sikap dan keterampilan siswa, dan dilakukan oleh berbagai unsur baik guru, wali kelas, orang tua bahkan siswa. Hal ini relevan dengan yang dikemukakan (Cusher, H. Kenneth, Averil McClelland, 2015) dalam bukunya yang berjudul Multicultural Education In Action bahwa penilaian dalam pembelajaran multikultural dilakukan dengan tehnis autentik yakni tidak terbatas pada prosedur penilaian tradisional, tetapi ditekankan pada pentingnya pengamatan anak-anak dalam kegiatan seghari-hari, pengumpulan pekerjaan anak-anak, dan komunikasi yang sedang berjalan dengan orang tua.

Diantara bentuk penilaian pembelajaran yang dilakukan di MIN I Kota Malang adalah melalui penilai tes dan non tes. Penilaian tes dilakukan untuk menilai kognitif siswa melalui Penilaian Harian (PH), Penilaian Tengah Semester (PTS) dan Penilaian Akhir Semester (PAS). Serta ulangan kenaikan kelas (UKK) semester genap. Sedangkan penilaian non tes (proses), dilakukan dengan tugas terstruktur (PR/tugas) atau tugas mandiri, penilian kegiatan pengembangan diri, dan sikap yang dilakukan melalui observasi kegiatan sehari-hari yang dilakukan oleh guru, wali kelas, siswa dan juga orang tua. Yakni melalui buku kobinsi, jurnal sikap yang berisi tentang catatan prilaku spiritual dan sosial siswa di 
lingkungan MIN I Kota Malang. Serta penilaian prilaku yang dinilai oleh teman melalui buku pamala dan pamalia. Melalui ragam jenis penilain di atas, maka MIN I Kota Malang telah menunjukkan praktek penilaian pembeljaran yang multikultural. Sehingga melalui penilaian tersebut semua aspek perkembangan dan kemajuan belajar siswa dapat diukur dan dinilai dengan transparan.

Dari hasil deskripsi aktivitas kegiatan pembelajaran sebagaimana uraian di atas, maka implementasi pembelajaran Pendidikan Agama Islam di MIN I Kota Malang dapat dikatakan telah didasarkan pada nilai-nilai multikultural. Hal ini dikarenakan dengan kegiatan/aktivitas pembelajaran guru yang mampu mengakomodir keragaman dan menanamkan nilai-nilai multikultural kepada siswa, mampu menjadikan pembelajaran lebih harmonis dan menyenangkan. Kreatifitas guru dalam menghidupkan suasana kelas dengan aktifitas atau kegiatan bertepuk-tepuk, menyanyi, dan bergerak juga akan menumbuhkan kegembiraan untuk mengikuti kegiatan belajar. Dalam buku Quantum Teaching disebutkan bahwa kelas diibaratkan sebuah rumah, tinggal bagaimana guru mampu mendesain suasana rumah sehingga mereka bisa belajar dengan mengalami kegembiraan, kepuasan, menerima dan tumbuh. Disinilah fungsi dari suasana gembira, karena kegembiraan akan membawa kegembiraan pula dalam belajar (De Porter, Bobby, 2010). Dengan suasana tersebut, secara tidak langsung guru telah berupaya untuk memberikan pengalaman belajar yang "memuaskan" sehingga dapat menenuhi kebutuhan psikologis siswa.

\section{KESIMPULAN}

Berdasarkan hasil paparan di atas, maka Implementasi proses pembelajaran Pendidikan Agama Islam Multikultural di MIN I Kota Malang dilakukan melalui pembelajaran mata pelajaran Pendidikan Agama Islam yang mengakui dan mengakomodasi keragaman kultur yang didasarkan pada nilai-nilai multikultural. Pengakuan keberagaman tersebut dilakukan melalui aktivitas pembelajaran di kelas dan di luar kelas. Di dalam kelas yang terintegrasi dalam pembelajaran mata pelajaran pendidikan Agama Islam meliputi Qur'an Hadis, Akidah Akhlak, Fiqih, dan Sejarah Kebudayaan Islam (SKI) dengan menggunakan pendekatan multikultural sejak perencanaan, pelaksanaan sampai penilai yang didasarkan pada nilai nilia- multikultural.

Selain di dalam kelas pembelajaran agama Islam yang didasarkan pada nilai multikultural ini juga dilakukan melalui program kegiatan madrasah dalam bentuk pembiasaan-pembiasaan. Selain itu, dalam proses pembelajaran peran guru/pendidik juga sentral, karena guru tidak hanya menjadi pengajar dalam arti mengajarkan materi dengan menggunakan beragam metode dan media pembelajran yang bervariatif dan menyenangkan, tetapi juga menunjukkan figur guru yang multikultural. Yakni memiliki sikap multikulturalis antara lain mampu menjadi teladan yang baik bagi siswa, guru mampu bersikap adil terhadap siswa, humanis, penyanyang serta menjunjung tinggi kesetaraan. Strategi/metode pembelajaran yang digunakan juga berorientasi pada pembelajaran aktif yang dapat mengembangakan seluruh potensi siswa, seperti; kerjasama, kerja kelompok, kelompok diskusi dan project, kontekstual, pembiasaan, dan modeling. Serta didukung dengan penggunaan media pembelajaran yang mampu mengakomodir keragaman modalitas belajar siswa. Lingkungan belajar juga didesain dengan baik dari aspek fisik maupun psikis-sosial sehingga menjadikan peserta didik merasa aman dan nyaman di dalam kelas.

Pembelajaran agama yang multikultural dapat menanamkan nilai-nilai Islam multikultural kepada peserta. Sehingga nilai-nilai anti-multikultural seperti diskriminasi dan kekerasan dapat dihindari. Oleh karena itu, proses pembelajaran Pendidikan Agama Islam multikultural direkomendasikan untuk diterapkan karena dapat memudahkan dalam 
Fita Mustafida: Implementasi Pembelajaran Pendidikan Agama Islam...

mencapai pada tujuan pendidikan agama Islam dalam mmbentuk pengetahuan, sikap dan keterampilan siswa secara padu dan seimbang.

Pembelajaran Pendidikan Agama Islam yang didasarkan pada nilai-nilai multikultural dapat memberikan pemahaman dan kesadaran bagi lembaga pendidikan khususnya guru akan pentingnya menghargai keragaman peserta didik dalam membina pengetahuan sikap dan keterampilan, yang berimplikasi pada praktek pembelajaran yang mampu mengakomodir keragaman siswa baik dari aspek kemampuan, gender, umur, bahkan latar belakang orang tua.

Oleh sebab itulah, guru perlu mengembangkan berbagai strategi dan metode pembelajaran khususnya guru mata pelajaran Pendidikan Agama Islam yang seringkali menggunakan pendekatan konvensional dan doktriner beralih pada pendekatan pembelajaran aktif yang bisa mengembangakan seluruh potensi yang dimiliki oleh siswa, yang menedepankan pada prinsip-prinsip kerjasama dan saling menghormati, seperti kerja kelompok, kelompok diskusi dan project yang dilaksanakan dalam hubungan yang saling menerima dan menghargai, akrab, terbuka, dan hangat.

\section{DAFTAR PUSTAKA}

Aly, A. (2015). Studi Deskriptif Tentang Nilai-Nilai Multikultural dalam Pendidikan di Pondok Pesantren Modern Islam Assalaam. Jurnal Ilmiah Pesantren, Volume I,.

Baidhawy, Z. (2005). Pendidikan Agama Berwawasan Multikultural. Jakarta: Erlangga.

Banks, J. A. (2010). Multicultural Education: Issues and Perspectives (seventh edition). United States: John Wiley \& Sons.

Cikusin, Y. (2006). Relasi BPD-Kepala Desa dan Transformasi Sosial. Program Pascasarjana Universitas Airlangga.

Creswell, W. J. (2015). Penelitian Kualitatif dan Desain Riset: Memilih diantara Lima Pendekatan. Yogyakarta: Pustaka Pelajar.

Cusher, H. Kenneth, Averil McClelland, and P. S. (2015). Human Diversity in education (an intercultural approach, eigth edition). New York: McGraw Hill Education.

De Porter, Bobby, trj. A. N. (2010). Quantum Teaching (Orchestrating Student Sucses). Terjemah Quantum Teaching (mempraktekkan quantum learning di ruang-ruang kelas). Bandung: Kaifa.

Ghofur, A. F. M. (2019). Strategi Pengelolaan Kelas Multikultural. Malang: UIN Maliki Press.

Hanifah. (2010). Penelitian Etnografi dan Grounded Theory. Jakarta: Akademi Bahasa Asing Borobudur.

Jacobsen, David, Paul Enggen, D. K. (2009). Methods for Teaching (metode pengajaran meningkatkan belajar siswa TK_SMA), Yogyakarta: Pustaka Pelajar.

Kymlicka, Will. (2002). Kewargaan Multikultural (3rd ed.). Jakarta: LP3ES.

Mahfud, C. (2019). MULTICULTURAL EDUCATION-BASED SOCIAL SCIENCE INSTRUCTIONAL MODEL IN ISLAMIC SCHOOL. Lentera Pendidikan, VOL. 22 NO. Retrieved from http://journal.uinalauddin.ac.id/index.php/lentera_pendidikan/article/view/7118/6425

Misrawi, Z. (2013). Kesadaran Multikultural dan Deradikalisasi Pendidikan Islam: Pengalaman Bhinneka Tunggal Ika dan Qabul Al-akhar. Jurnal Pendidikan Islam, Volume II,.

Mulyasa, E. (2013). Pengembangan dan Implementasi Kurikulum 2013. Bandung: PT Remaja Rosdakarya.

Nata, A. (2005). Filsafat Pendidikan Islam. Jakarta: Gaya Media Pratama.

Race, R. (2015). Multiculturalism and Education (2nd edition) contempory issues in education studies. India: Bloomsbury. 
Rosyidi, I. (2009). Pendidikan Berparadigma Inklusif (upaya memadukan pengokohan akidah dengan pengembangan sikap toleransi dan kerukunan). Malang: UIN Press.

Slavin, R. E. (2009). Educational Phicology: Theory and Practice, 8th, Edition. New Jersey: Personal Education.

Smith, M. (2002). Curriculum Theory and Practice. London: Routledge.

Suryana, Y. dan R. (2015). Pendididikan Multikultural (suatu upaya penguat jati diri bangsa konsep-prinsip-implementasi. Bandung: IKAPI.

Zamroni. (2011). Pendidikan Demokrasi pada Masyarakat Multikultural. Yogyakarta: Gavin Kalam Utama. 